KS. TOMASZ MOSKAL* - LUBLIN

\title{
MSZAŁ KRAŚNICKI - ZABYTEK Z XV WIEKU
}

\section{Mszal w literaturze przedmiotu}

W 1922 roku ks. Ludwik Zalewski, charakteryzując bibliotekę w klasztorze kanoników regularnych w Kraśniku, zapisał: „Z osiemdziesięciu przeszło inkunabułów, jakie posiada Biblioteka Seminarium z Kraśnika, w spisie przesłanym Kurii Biskupiej, zaledwie kilka umieszczono. Nie zapisano również ozdoby biblioteki - rękopisów z XV w., oprócz Missale antiquissimum manuscripti [!] in pago[!], które to dzieło jest mszałem pergaminowym z końca XV stulecia, wspaniale iluminowanym, niestety zniszczonym iście po wandalsku" ${ }^{1}$. W cztery lata później Edward Chwalewik, prezentując w 1926 roku zbiory biblioteki Seminarium Duchownego w Lublinie podaje: ,,według spisu z r. 1887 Biblioteka Seminaryjna otrzymała z Kraśnika 1005 druków (w tym ok. 89 inkunabułów) i rękopisów, między którymi było 308 teologicznych, 374 kaznodziejskich, 66 filozoficznych, 125 historycznych, 92 prawne, 72 biblijne i 48 Ojców Kościoła (w tym Missale antiquissimum manuscripti in pago, rkps ilumin. pergam. z XV w.)"2. Mszał był przedmiotem badań ks. Mieczysława Bochyńskiego ${ }^{3}$, ks. Czesława Krakowiaka ${ }^{4}$, Ewy Zielińskiej ${ }^{5}$. W wydanym w ubiegłym roku opracowaniu Rękopisy w zbiorach kościelnych, w odniesieniu do mszału z Kraśnika czytamy przy opisie Bi-

* Ks. Tomasz Moskal - dr hab. historii Kościoła; prof. w Katedrze Historii Kościoła w Czasach Najnowszych, Metodologii i Nauk Pomocniczych Historii Kościoła; Instytut Historii Kościoła i Patrologii KUL; e-mail: tomos@kul.pl

${ }^{1}$ L. Zalewski, Biblioteka Ks. Ks. Kanoników Regularnych Laterańskich w Kraśniku, Lublin 1922, s. 30.

${ }^{2}$ E. Chwalewik, Zbiory polskie, t. 1, Warszawa-Kraków 1926, s. 358.

${ }^{3}$ M. Bochyński, Zasób sekwencji Mszału z Kraśnika z przełomu XIV/XV wieku, „Archiwa Biblioteki i Muzea Kościelne”, 47 (1983) s. 175-238.

${ }^{4}$ Cz. Krakowiak, Mszał z Kraśnika, w: Encyklopedia Katolicka (dalej: EK), t. 13, Lublin 2009, kol. 463.

${ }^{5}$ E. Zielińska, Kultura intelektualna Kanoników Regularnych z klasztoru w Kraśniku w latach 1469-1563, Lublin 2002, s. 111, 133-134; E. Zielińska, Biblioteka klasztoru kanoników regularnych w Kraśniku w drugiej połowie XV wieku, w: Klasztor w kulturze średniowiecznej Polski, red. A. Pobóg-Lenartowicz, M. Derwich, Opole 1995, s. 105-112. 
blioteki seminarium duchownego w Lublinie: „Kraśnik - kanonicy regularni laterańscy: 14 kodeksów z XV w., w tym m.in. mszał z ok. 1400 r. ilum. (miniatury W większości wycięte)" ${ }^{\prime}$.

\section{Czas i miejsce powstania}

Badacze mszału w XX wieku podejmowali próby przybliżonej datacji jego powstania. Ks. Julian Wojtkowski w 1954 roku, analizując znajdujące się w księdze teksty o Niepokalanym Poczęciu NMP, ustalił datę powstania kodeksu na przełom XIV i XV wieku. Z kolei ks. Wacław Schenk oraz ks. Wojciech Danielski ustalają datę powstania rękopisu na ok. 1400 rok. Podany czas należy skorelować z fundacją klasztoru Kanoników Regularnych w Krakowie, która miała miejsce w $1405 \mathrm{roku}^{7}$. Konwent przejął księgi liturgiczne z parafią Bożego Ciała jak również otrzymał je w darze od macierzystego klasztoru w Kłodzku. W odniesieniu do krakowskiej wspólnoty wiemy, że działało w nim skryptorium. Jednym ze charakterystycznych produktów tego miejsca jest wielotomowy antyfonarz ${ }^{8}$. Znany jest z imienia zakonnik Szymon, który był przeorem, ale zajmował się również kopiowaniem ksiąg. $Z$ tego skryptorium korzystano przy przygotowaniach do wyposażenia w stosowne księgi (głównie liturgiczne) nowych fundacji: w Kłobucku (1454), Kraśniku (1468) oraz Kurozwękach (1487). Wszystko więc wskazuje, że miejscem powstania mszału kraśnickiego był Kraków. Cytując Iwonę Pietrzkiewicz ,Za produkt kazimierskiego skryptorium uważany jest w literaturze iluminowany Mszał kraśnicki, istotny ze względu na wprowadzone do niego na przełomie XV/XVI w. uzupełnienia mające na celu przystosowanie go do liturgii zakonnej"9.

Informacja o obecności mszału w Kraśniku pochodzi dopiero z 1580 roku. W tekście bowiem odnajdujemy zapis: F[rater] Andr[eas] Rziczicki canonicus regularis con[ventus] Crasnicensis, a. 1580 presbyter factus". Ponadto z drugiej połowy XVI wieku pochodzi szereg zapisków, odnoszących się do liturgii (modlitwy, formularze mszalne, uwagi rubrycystyczne). Świadczy to o użytkowaniu kodeksu w tym czasie.

Nie bez znaczenie pozostają w tym kontekście dwa fakty. Otóż, od ponad stu lat triumfalnie kroczy po Europie (w tym i Polsce od 1474 roku) sztuka drukarska ${ }^{10}$. Druk w większości wypierał kodeksy rękopiśmienne, aczkolwiek znajdowały się w tym względzie chlubne wyjątki. Wśród nich wybija się inicjatywa biskupa płockiego Erazma Ciołka, który przyczynił się do powstania w latach 1513-1518 mszału. Zawierał on kalendarz liturgiczny, ewangelie, tablice paschalne, rubryki, części stałe, prefacje oraz formularze mszalne na po-

\footnotetext{
${ }^{6}$ Rękopisy w zbiorach kościelnych, opr. T. Makowski, Warszawa 2014, s. 221.

${ }^{7}$ Zob. K. Łatak, Kanonicy regularni laterańscy na Kazimierzu w Krakowie do końca XVI wie$k u$, Ełk 1999.

${ }^{8}$ H. Pieńkowska, Średniowieczne scriptorium $w$ klasztorze kanoników regularnych $w$ Krakowie, „Sprawozdania z Czynności i Posiedzeń Polskiej Akademii Umiejętności”, 49 (1948) nr 7, s. 335-336.

${ }^{9}$ I. Pietrzkiewicz, Biblioteka kanoników regularnych w Krakowie w XV i XVI wieku, Kraków 2003, s. 74.

${ }^{10}$ Zob. H. Szwejkowska, Książka drukowana XV-XVIII wieku. Zarys historyczny, Wrocław 1983; B. Bieńkowska, Książka na przestrzeni dziejów, Warszawa 2005.
} 
szczególne okresy roku liturgicznego proprium de tempore i według cyklu świąt proprium de sanctis jak również formularze dla świętych. Bogata dekoracja tego dzieła związana jest wyraźnie z warsztatem Stanisława Samostrzelnika. Mamy tu bowiem do czynienia $\mathrm{z}$ pierwszymi renesansowymi miniaturami w których widoczne są zapożyczenia czerpane z dzieł Albrechta Dürera (1471-1528) ${ }^{11}$. Ciołkowi nie ustępował biskup Piotr Tomicki. Podczas jego pobytu na katedrze biskupiej w Przemyślu (1514-1520), w 1516 roku otrzymał od mistrza z Mogiły Missale illuminatum cum imaginibus Petro episcopo Premislienis. Jak można sądzić z tytułu, mszał ten został wykonany w związku z nominacją Tomickiego na biskupstwo przemyskie ${ }^{12}$. Drugim ważnym wydarzeniem, odnoszącym się do tego okresu, była reforma liturgiczna zapoczątkowana uchwałami Soboru trydenckiego (1545-1563). W 1570 roku papież Pius V w konstytucji apostolskiej Quo primum promulgowanej 14 lipca, nakazał korzystanie z Mszału rzymskiego, zunifikowanego dla całego kościoła łacińskiego ${ }^{13}$. Fakt, że w tym czasie księgę nadal używano, może wypływać ze szczególnego znaczenia tego kodeksu dla klasztoru w Kraśniku. Może to być potwierdzeniem jego krakowskiego rodowodu i przybycia do Kraśnika z grupą pierwszych zakonników. Powyższe wywody potwierdzają badania ks. Zalewskiego. Wykazał on bowiem, ze pierwszy przeor klasztoru w Kraśniku, Jan z Bytomia, przybywając do miejsca nowej fundacji w 1469 roku, wziął ze sobą książki z biblioteki klasztoru krakowskiego ${ }^{14}$. Były to z pewnością przede wszystkim księgi liturgiczne. Służyły one pomocą w sprawowaniu liturgii w klasztorze. W przypadku mszału, możemy stwierdzić jego użytkowanie jeszcze w drugiej połowie XVI wieku. Po reformie trydenckiej stał się cennym zabytkiem, przechowywanym w klasztornej bibliotece do kasaty klasztoru w 1864 roku. Przez 13 lat pozostawał w Kraśniku. W 1877 roku, został z innymi książkami, został przewieziony do Biblioteki Seminarium Duchownego w Lublinie. Jednakże dopiero po II wojnie światowej zostały one skatalogowane i uporządkowane ${ }^{15}$.

\section{Opis zewnętrzny}

Kodeks nie posiada oryginalnej oprawy. Zapisana na wewnętrznej stronie przedniej okładki data 1545 ,hoc missale est introligatum anno virginei partu 1545" odnosi się do wtórnego oprawienia. Skórzana okładzina posiadała liczne okucia stalowe, po których pozostały ślady. Podczas oprawiania w XVI wieku, krawędzie kart zostały przycięte do wymiarów $37,5 \times 28 \mathrm{~cm}$. Użytkowanie kodeksu pozostawiło liczne ślady w postaci zabrudzeń, szczególnie widocznych na narożnikach, przetarć tekstu. Widoczne są zerwania szycia bloku. Stan zabytku przed konserwacją, której został poddany w 2009 roku opisano następująco: „Pergamin charakteryzowała duża deformacja kart, był sztywny i zdeformowany

${ }^{11}$ Szerzej na ten temat pisze B. Miodońska, Miniatury Stanisława Samostrzelnika, Warszawa 1983.

${ }^{12}$ B. Bieńkowska, H. Chamerska, Tysiąc lat książki i bibliotek w Polsce, Wrocław 1992, s. 20.

${ }^{13}$ S. Koperek, Mszat, EK, t. 13, Lublin 2009, kol. 462.

${ }^{14}$ Zalewski, Biblioteka Ks. Ks. Kanoników, s. 7.

${ }^{15}$ Bochyński, Zasób sekwencji, s. 195-196. 
z licznymi ubytkami, wyciętymi najczęściej w miejscach iluminacji i inicjałów oraz w partiach marginesów dolnych i bocznych. W kartach papierowych: papier bibulasty, kruchy, uszkodzone krawędzie i rozległe ubytki papieru, niektóre składki lub karty były wyrwane. Blok był niestabilny, poluzowany; brak tylnych elementów zapinek z paskami dociskowymi”. Oprawa znajdowała się w bardzo złym stanie i wymagała gruntownej konserwacji. Zachowany fragment skóry był całkowicie przesuszony, kruchy i łamliwy. Zauważono również duże zniszczenia mechaniczne $\mathrm{w}$ obrębie grzbietu, spowodowane przesuszeniem oraz przy okładzinach - spowodowane użytkowaniem. Kodeks miał liczne i rozlegle ubytki okuć stalowych. Cały kodeks wymagał oczyszczenia, odplamienia, uzupełnienia ubytków pergaminu, papieru, skóry, desek, okuć i wzmocnienia miejsc uszkodzonych $\mathrm{z}$ tekstem oraz innych słusznych działań celem zabezpieczenia zabyt$\mathrm{ku}^{16}$.

\section{Zawartość}

Kodeks składa się z dwóch części. Pierwsza zawiera 24 ponumerowane składki i liczy 456 stron. Druga, która datowana jest na koniec XV wieku, posiada 7 kart pergaminowych i 4 papierowe. Niestety, od XV wieku zabytek został zdekompletowany. Widoczny jest brak kilku składek, pojedynczych kart. Jak zaznaczono wyżej, wycięte zostały iluminacje, inicjały, jak również w wielu miejscach ozdobne bordiury.

W pierwszej części mszału znajdują się:

- Kalendarz diecezji krakowskiej pisany w dwóch kolumnach. Festa fori zostały zapisane czerwonym kolorem. Kalendarz zapisano na 3 kartach nieliczbowanych. Brakuje w nim świat praskich, ołomunieckich, wrocławskich. Widoczne jest podobieństwo do kalendarzy krakowskich końca XIV i początku XV wieku. Jego powstanie datuje się na okres po 1394 roku (jak festa fori występują już Niepokalane Poczęcie NMP (8 XII), Nawiedzenie NMP (2 VII), a przed 1420 rokiem, gdyż wspomnienia św. Hieronima (30 IX) oraz św. Augustyna (28 VIII) występują jako fest chori;

- Proprium de tempore Obejmuje okres od 1 niedzieli Adwentu do Wielkiej Soboty, k 11r - 101v;

- Teksty prefacji oraz zmienne części kanonu, k 103r;

- Teksty i nuty prefacji, dopisane w końcu XV w, k 110r $-114 \mathrm{v}=2$ nieliczbowane;

- Kanon mszalny, którego karty posiadają dodatkową numerację Zostały zapisane ręka innego i jak się wydaje wcześniejszego kopisty Ks Bochyński przypuszcza, że mogą pochodzić z innego kodeksu, k 105r $-108 \mathrm{v}$

- Temporale od niedzieli Wielkanocy do XXIII niedzieli po Trójcy Świętej Pozostała część została wycięta, k 114r - 173v;

${ }^{16}$ E. Oszajca, Konserwacja rękopisu „,Mszał z Kraśnika” (ok. 1400 r.), inkunabułów i starodruków ze zbiorów Biblioteki Metropolitalnego Seminarium Duchownego w Lublinie, „FIDES - Biuletyn Bibliotek Kościelnych", 1-2 (28-29) (2009) s. 82. 
- Proprium Sanctorum, (od oktawy św Agnieszki do formularza o św Katarzynie), k 173-212v;

- Commune Sanctorum, (min o ewangelistach i męczennikach), k 212v $-229 \mathrm{v}$

- Msze wotywne na poszczególne dni tygodnia (O Duchu Świętym, O aniołach, O Krzyżu Świętym, O NMP po Bożym Narodzeniu, w okresie między Wniebowstąpieniem a Zesłaniem Ducha Swiętego, w soboty), k 229 - 231v;

- Msze wotywne w różnych intencjach.

Na zawartość drugiej części kodeksu składają się: nowe wprowadzenie do liturgii oraz formularze mszalne i prozarium, czyli zbiór sekwencji mszalnych. $\mathrm{W}$ całym kodeksie jest ich 54, w tym 6 polskich ${ }^{17}$. Warto w tym miejscu wskazać istnienie jeszcze jednego kodeksu, a mianowicie Komentarza antyfon, hymnów i sekwencji z 1445 roku, wywodzącego się z klasztoru kraśnickiego. Jest on obecnie własnością Biblioteki Kapitulnej we Włocławku ${ }^{18}$.

Pomimo wielu ubytków, Mszał kraśnicki jest cennym zabytkiem liturgicznym odnoszącym się tak do przedrozbiorowej diecezji krakowskiej, jak i obecności w jej granicach kanoników laterańskich i ich troski o liturgię.

słowa kluczowe: księgi liturgiczne; mszał; Kanonicy Regularni Laterańscy; Kraśnik

\section{BIBLIOGRAFIA}

\section{Opracowania}

Bieńkowska B., Chamerska H., Tysiac lat ksiażki i bibliotek w Polsce, Wrocław 1992.

Bieńkowska B., Ksiązka na przestrzeni dziejów, Warszawa 2005.

Bochyński M., Zasób sekwencji Mszału z Kraśnika z przełomu XIV/XV wieku, „Archiwa Biblioteki i Muzea Kościelne”, 47 (1983) s. 175-238.

Boguniowski J.W., Rozwój historyczny ksiag liturgii rzymskiej do Soboru Trydenckiego i ich recepcja w Polsce, Kraków 2001.

Chwalewik E., Zbiory polskie, t. 1, Warszawa-Kraków 1926.

Krakowiak Cz., Mszat z Kraśnika, w: Encyklopedia Katolicka, t. 13, Lublin 2009, kol. 463.

Łatak K., Kanonicy regularni laterańscy na Kazimierzu w Krakowie do końca XVI wieku, Ełk 1999.

Miodońska B., Miniatury Stanisława Samostrzelnika, Warszawa 1983.

\footnotetext{
${ }^{17}$ Bochyński, Zasób sekwencji, s. 236-237.

${ }^{18}$ J.W. Boguniowski, Rozwój historyczny ksiag liturgii rzymskiej do Soboru Trydenckiego i ich recepcja w Polsce, Kraków 2001, s. 140; B. Iwańska-Cieślik, Biblioteka kapituly katedralnej we Włocławku, Bydgoszcz 2013, s. 182.
} 
Oszajca E., Konserwacja rękopisu „, Mszał z Kraśnika” (ok. 1400 r.), inkunabułów i starodruków ze zbiorów Biblioteki Metropolitalnego Seminarium Duchownego w Lublinie, „FIDES - Biuletyn Bibliotek Kościelnych”, 1-2 (28-29) (2009) s. 82.

Pieńkowska H., Średniowieczne scriptorium $w$ klasztorze kanoników regularnych $w$ Krakowie, „Sprawozdania z Czynności i Posiedzeń Polskiej Akademii Umiejętności”, 49 (1948) $\mathrm{nr}$ 7, s. 335-336.

Rękopisy w zbiorach kościelnych, opr. T. Makowski, Warszawa 2014.

Szwejkowska H., Ksiązka drukowana XV-XVIII wieku. Zarys historyczny, Wrocław 1983.

Zalewski L., Biblioteka Ks. Ks. Kanoników Regularnych Laterańskich w Kraśniku, Lublin 1922.

Zielińska E., Biblioteka klasztoru kanoników regularnych $w$ Kraśniku $w$ drugiej połowie $X V$ wieku, w: Klasztor w kulturze średniowiecznej Polski, red. A. Pobóg-Lenartowicz, M. Derwich, Opole 1995, s. 105-112.

Zielińska E., Kultura intelektualna Kanoników Regularnych z klasztoru w Kraśniku w latach 1469-1563, Lublin 2002.

\section{KRAŚNIK MISSAL - MONUMENT FROM THE $15^{\text {TH }}$ CENTURY}

\section{Summary}

Kraśnik missal - liturgical manuscript dated for the beginning the $15^{\text {th }}$ century, probably product scriptorium by the monastery of Canons Regular in Cracow. In the $16^{\text {th }}$ century his presence authenticated at the monastery in Kraśnik. In the XIX century transported to the seminar library in Lublin. He consists of two parts, containing the calendar of the Cracow diocese and liturgical texts among others.

Keywords: liturgical books; missal; Canons Regular of the Lateran; Kraśnik 